\title{
Short Communication: Pattern of antibiotic resistance on extended-spectrum beta-lactamases genes producing Escherichia coli on laying hens in Blitar, Indonesia
}

\author{
FRESHINTA JELLIA WIBISONO ${ }^{1}$, BAMBANG SUMIARTO ${ }^{2}$, TRI UNTARI ${ }^{3}$, \\ MUSTOFA HELMI EFFENDI ${ }^{4,5, \vartheta}$, DIAN AYU PERMATASARI ${ }^{5}$, ADIANA MUTAMSARI WITANINGRUM ${ }^{5}$ \\ ${ }^{1}$ Doctoral Program in Veterinary Science, Faculty of Veterinary Medicine, Universitas Gadjah Mada. Jl. Fauna No. 2, Karangmalang, Yogyakarta 55281, \\ Indonesia \\ ${ }^{2}$ Department of Veterinary Public Health, Faculty of Veterinary Medicine, Universitas Gadjah Mada. Jl. Fauna No. 2, Karangmalang, Yogyakarta 55281, \\ Indonesia \\ ${ }^{3}$ Department of Microbiology, Faculty of Veterinary Medicine, Universitas Gadjah Mada. J1. Fauna No. 2, Karangmalang, Sleman55281, Yogyakarta, \\ Indonesia \\ ${ }^{4}$ Halal Research Center, Universitas Airlangga. Jl. Raya Mulyorejo, Surabaya 60115, East Java, Indonesia. Tel./fax.: +62-31-5915551, \\ vemail: mheffendi@yahoo.com \\ ${ }^{5}$ Department of Veterinary Public Health, Faculty of Veterinary Medicine, Universitas Airlangga. Jl. Raya Mulyorejo, Surabaya 60115, East Java, Indonesia
}

Manuscript received: 24 July 2020. Revision accepted: 14 September 2020.

\begin{abstract}
Wibisono FJ, Sumiarto B, Untari T, Effendi MH, Permatasari DA, Witaningrum AM. 2020. Short Communication: Pattern of antibiotic resistance on extended-spectrum beta-lactamases genes producing Escherichia coli on laying hens in Blitar, Indonesia. Biodiversitas 21: 4631-4635. The aims of this study were to determine the susceptibility pattern of phenotypic antibiotics on extendedspectrum beta-lactamases (ESBL) genes and genotype profiles of ESBL producing Escherichia coli strains isolated from cloacal samples of laying hens in Blitar. A total of 165 cloacal swab samples were successfully isolated 145 E. coli strains during the study taken from 5 subdistricts in Blitar. All the strains were examined for antibiotic resistance patterns by disk diffusion method with doubledisk synergy test (DDST), followed testing with VITEK ${ }^{\circledR} 2$ methods, molecular identification of ESBL coding genes using PCR. The results of this study showed that the characterization of nucleotide analysis from PCR amplification of ESBL-producing $E$. coli bacteria isolated from laying hens in Blitar showed that eight isolates were the dominant of CTX gene, followed by the TEM encoding gene of two isolates, and the SHV coding gene as much as one isolate. The presence of more than 1 encoding genes in the $E$. coli bacterial isolate was seen in 1 isolate, where the isolate carried the CTX gene and the SHV gene as well. All ESBL producing E. coli isolates were resistant to amoxicillin, ampicillin, cefazolin, cefotaxime, and ceftriaxone, and these ESBL isolates were more than $70 \%$ resistant to gentamicin, aztreonam, and trimethoprim/sulfamethoxazole. These results indicated that poultry is a potential reservoir for ESBLproducing $E$. coli. The presence of ESBL-producing E. coli in poultry requires strengthening antibiotic policy. This is important because the regulation of antibiotic use in poultry is gaining momentum to increase animal productivity and food safety in Blitar, Indonesia.
\end{abstract}

Keywords: Antimicrobial resistance, ESBL genes, Escherichia coli, food safety

\section{INTRODUCTION}

The use of antibiotics in animal husbandry provides benefits for animals and farmer, but can pose a risk of antibiotic resistance (Suardana et al. 2014). The use of antibiotics without clear indications has caused many bacteria to become resistant (Kurniawati et al. 2015). In developing countries, including in Indonesia, very little data on the prevalence of antibiotic resistance is found. Development of an effective surveillance system needs to be done, to monitor the emergence of antibiotic resistance (Kurniawati et al. 2015). The use of antibiotics in animals can promote the development of antibiotic resistance, one of which is Escherichia coli which produces extendedspectrum beta-lactamases (ESBL) enzyme (Hammerum et al. 2014).

Extended-spectrum beta-lactamases is an enzyme that causes resistance to a wider spectrum, third-generation cephalosporins, and monobactams but does not affect cephamycin or carbapenem that cause resistance so that antibiotics become ineffective (Paterson and Bonomo 2005). Continuous exposure of large amounts of betalactam antibiotics induces the production and mutation of the beta-lactamase enzyme. ESBL is derived from the mutated beta-lactamase enzyme. This mutation causes an increase in the enzymatic activity of beta-lactamase, therefore this enzyme can hydrolyze third-generation cephalosporins and aztreonam (Lim et al. 2013; Kang et al. 2017). ESBL-producing bacteria can also be resistant to antibiotics from aminoglycoside, fluoroquinolone, tetracycline, chloramphenicol, and sulfamethoxazoletrimethoprim (Brower et al. 2017; Sudarwanto et al. 2017).

Extended-spectrum beta-lactamases is present in mutated genes often found, namely the type of cefotaximase (CTX-M), temoneira (TEM), and variable sulfhydryl (SHV). The CTX-M, TEM, and SHV genes in 
ESBLproducing E. coli are genes that encode and produce enzymes that can hydrolyze beta-lactam rings from betalactam antibiotics and third-generation cephalosporins. The diagnosis with molecular detection is a test for the betalactam ring from beta-lactam class of antibiotics and cephalosporins (Biutifasari 2018). Genotypic confirmatory to see the existence of ESBL encoding genes in $E$. coli bacteria can be carried out by using PCR (Bradford 2001; Putra 2019). The highest prevalence of ESBLproducing bacteria with CTX-M, TEM, and SHV is the most common type of ESBL in poultry (Saliu et al. 2017). Previous research conducted by Brower (2017) found that ESBL producing $E$. coli in India was about $42 \%$ in laying hens.

This study was expected to provide a genetic picture of ESBL producing E. coli. Data on the existence of reports based on the encoding genes of ESBL producing $E$. coli is clear evidence for monitoring antibiotic use in commercial chicken farms.

\section{MATERIALS AND METHODS}

\section{Isolation and identification of Escherichia coli}

Isolation and identification of $E$. coli were carried out with reference to Effendi et al. (2019). The total samples used in the study were 165 cloacal swabs from 5 subdistricts in Blitar Regency. Cloacal swab samples were stored in the Amies Swab Viscosa (deltalab, Spain) transported to the laboratory in cold temperatures conditions for the isolation of E. coli bacteria (Seni et al. 2016). Isolation of E. coli bacteria using selective media MacConkey Agar no. 3 CM0115 (Oxoid, England) and differential media Eosin Methylene Blue Agar CM0069 (Oxoid, England), incubated at $35-37^{\circ} \mathrm{C}$ for $20-24$ hours. Pure E. coli colonies were identified by biochemical testing of IMVIC (Indol-Motility, Methyl Red, Voges Proskauer, Citrate) and TSIA (Triple Sugar Iron Agar) (Effendi et al. 2019).

\section{ESBL confirmation and antibiotic susceptibility testing}

Double disc synergy test (DDST) method was used to evaluate the presence of inhibitory zones of ESBL activity with clavulanic acid using the Kirby-Bauer disk diffusion method on Mueller-Hinton agar (Merck, Germany). The antibiotic discs of amoxicillin-clavulanic 30 $\mu$ g (Oxoid, England), cefotaxime 30 $\mu$ g (Oxoid, England), ceftazidime $30 \mu \mathrm{g}$ (Becton Dickinson, USA), and aztreonam 30 $\mu \mathrm{g}$ (Oxoid, England) were used in this method. Culture was incubated at $35-37^{\circ} \mathrm{C}$ for $18-24$ hours (Putra et al. 2020; CLSI 2017). The inhibition zone that appeared on the cup after incubation was measured based on CLSI guidelines showing an inhibition zone $\leq 27 \mathrm{~mm}$ in cefotaxime, inhibition zone $\leq 22 \mathrm{~mm}$ in ceftazidime, inhibition zone $\leq$ $27 \mathrm{~mm}$ in aztreonam, and there was a synergy between cefotaxime/ceftazidime with a combination of $\leq 22 \mathrm{~mm}$ in ceftazidime, inhibition zone $\leq 27 \mathrm{~mm}$ in aztreonam, and there was a synergy between cefotaxime/ceftazidime with amoxicillin-clavulanic in the form of synergy expansion of the inhibition zone between the two disks and there is an increase in the inhibition zone $\geq 5 \mathrm{~mm}$ between the diameter of the cephalosporin disk and the cephalosporinclavulanate disk assert that the $E$. coli bacteria is positive ESBL (CLSI 2017).

The antibiotic sensitivity test of ESBL-producing $E$. coli bacteria by the DDST method was then confirmed by the VITEK $^{\circledR} 2$ method. The bacterial suspension was homogenized and bacterial turbidity of 0.50 to 0.63 McFarland was made using VITEK $^{\circledR} 2$ DensiCHEK. Antimicrobial susceptibility and phenotypic detection of ESBL generators were used AST N280 cards (bioMérieux, Marcy-L'Étoile, France). Results were analyzed automatically by the system and interpreted as sensitive, intermediate, and resistant (Brower et al. 2017; Biomerioux 2017; Putra et al. 2020).

\section{Characterization of CTX, TEM, and SHV genes by Polymerase Chain Reaction (PCR)}

The Extended spectrum beta-lactamase-producing $E$. coli bacteria which has been phenotypically confirmed by DDST and VITEK ${ }^{\circledR} 2$ compact methods were then genotypically confirmed by further analyzing the presence of ESBL genes CTX subtypes, TEM, and SHV using molecular identification of PCR. Bacterial DNA was isolated with the QIAamp ${ }^{\circledR}$ DNA mini kit (QIAGEN, Germany). E. coli ATCC 35218 was used as a positive control standard for strains of ESBL-producing bacteria and $E$. coli ATCC 25922 was used as a negative control or non-ESBL-producing bacteria. The PCR results were visualized by electrophoresis using $2 \%$ agarose gel (Invitrogen, USA). The primers used to encode CTX encoding gene refer to Ali et al. (2016), and the primers used to encode the TEM and SHV coding genes refer to Kurekci et al. (2017), as shown in Table 1.

\section{Ethical clearance}

Cloacal swabs were used in this study, hence ethical clearance was not necessary. Cloacal swab samples were collected from laying hens farms in Blitar, East Java province, Indonesia.

\section{RESULTS AND DISCUSSION}

\section{Results}

The results of isolation and identification of laying cloak swab samples from a total of 165 samples revealed that $87.9 \%$ were identified as presumptive Escherichia coli on MacConkey agar media. In order to be identified with $E$. coli colonies, they had a small round shape and semimucoid reddish-pink colonies whereas, on Eosin Methylene blue to metallic green colony. The bacterial culture was then confirmed by biochemical tests using IMVIC and TSIA.

The results of the ESBL-producing $E$. coli confirmation on laying hens cloacal swabs with the double-disc synergy test (DDST) method showed 10 (6.89\%) positive ESBL isolates. The results were then confirmed by the automatic VITEK $^{\circledR} 2$ compact method which showed $100 \%$ E. coli results (Table 2). Cefotaxime synergy with the combination of amoxicillin-clavulanate in the form of an expansion of 
the inhibition zone between the two disks showed that ESBL is positive. This result is in accordance with Savira (2014). Positive results on ESBL-producing bacteria confirmed that there was an increase in inhibition zones $\geq 5$ $\mathrm{mm}$ between the diameter of the cephalosporin disk and the cephalosporin-clavulanate disk combination revealed an ESBL positive germ (CLSI 2017).

Molecular identification as shown in Table 3 showed that 8 isolates $(8 / 10,80 \%)$ were isolates of Escherichia coli bacteria producing ESBL encoding CTX gene, 2 isolates $(2 / 10,20 \%)$ encoding TEM gene, and 1 isolate $(1 / 10,10 \%)$ encoding the TEM SHV gene. The CTX encoding gene is most commonly found in E. coli. CTX type enzymes have hydrophilic ability against cephalosporins, especially cefotaxime, so-called CTX (Saliu et al. 2017). Molecular identification showed visualization of CTX, TEM, and SHV gene fragment bands (Figures 1 and 2). Positive results on the CTX gene showed electrophoresis results of samples describing the same fragments as positive controls with a gene length of $550 \mathrm{bp}$, as shown on Figure 1. The positive results of the TEM gene on ESBL showed the results of electrophoresis samples illustrating the same fragments as positive controls with a gene length of 1086 bp. The positive results of the SHV gene on ESBL showed the results of electrophoresis samples illustrating the same fragments as positive controls with a gene length of $927 \mathrm{bp}$ (Ali et al. 2016; Kurekci et al. 2017), as shown on Figure 2.

The results of the sensitivity test were in line with the sensitivity test on broiler chickens in the Bogor slaughterhouse of $93.7 \%$ (ampicillin), 75\% (streptomycin), and $68.75 \%$ (erythromycin) (Masruroh et al. 202016). A large number of antibiotics used in laying hens are also used for human therapy, resulting in a selection of pathogenic bacteria that are resistant to several drugs. Sensitivity tests were carried out on all bacterial isolates obtained from bacterial culture.

Figures 1 and 2 showed the spread of ESBL-producing E. coli occurring in 3 sub-districts from 5 sub-districts of the sampling area. Srengat subdistrict has 6 isolates, Talun subdistrict has 1 isolate, and Kademangan subdistrict there are 3 isolates of ESBL-producing E. coli isolates, while Ponggok subdistrict and Udanawu subdistrict are not found any E. coli producing ESBL.

Table 1. Nucleotide sequence of the primers used in PCR

\begin{tabular}{|c|c|c|c|}
\hline Target & $\begin{array}{l}\text { Sequence } \\
\text { (amplicon sizes) }\end{array}$ & 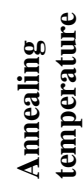 & 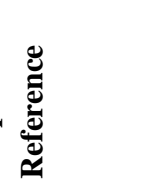 \\
\hline $\begin{array}{l}\text { CTX } \\
\text { gene }\end{array}$ & $\begin{array}{l}\text { F: CGC TTT GCG ATG TGC AG } \\
\text { R: ACC GCG ATA TCG TTG GT } \\
\text { (Amplicon 550-bp) }\end{array}$ & $54{ }^{\circ} \mathrm{C}$ & $\begin{array}{l}\text { Ali et al. } \\
2016\end{array}$ \\
\hline $\begin{array}{l}\text { TEM } \\
\text { gene }\end{array}$ & $\begin{array}{l}\text { F: ATAAAATTCTTGAAGACGAAA } \\
\text { R: GACAGTTACCAATGCTTAATC } \\
\text { (Amplicon: } 1080 \mathrm{bp} \text { ) }\end{array}$ & $59{ }^{\circ} \mathrm{C}$ & $\begin{array}{l}\text { Kurekci et } \\
\text { al. } 2017\end{array}$ \\
\hline $\begin{array}{l}\text { SHV } \\
\text { gene }\end{array}$ & $\begin{array}{l}\text { F: CGGCCTTCACTCAAGGATGTA } \\
\text { R: GTGCTGCGGGCCGGATAAC } \\
\text { (Amplicon: } 927 \text { bp) }\end{array}$ & $59^{\circ} \mathrm{C}$ & $\begin{array}{l}\text { Kurekci et } \\
\text { al. } 2017\end{array}$ \\
\hline
\end{tabular}

Tabel 2. Extended-spectrum beta-lactamases (ESBL) producing Escherichia coli in Blitar, Indonesia

\begin{tabular}{lcccc}
\hline \multirow{2}{*}{ Location } & \multirow{2}{*}{$\begin{array}{c}\text { Sample } \\
\text { size }\end{array}$} & $\begin{array}{c}\text { Escherichia } \\
\text { coli }\end{array}$ & \multicolumn{2}{c}{ ESBL Confirmation } \\
\cline { 4 - 5 } & 40 & 31 & DDST & VITEK $^{\circledR}$ 2 \\
\hline Ponggok & 45 & 43 & 6 & - \\
Srengat & 45 & 30 & - & - \\
Udanawu & 35 & 18 & 1 & 1 \\
Talun & 20 & 23 & 3 & 3 \\
Kademangan & 25 & 145 & 10 & 10 \\
\hline Total & 165 & & & \\
\hline
\end{tabular}

Table 3. Phenotypic and genotypic profiles of ESBL-producing Escherichia coli isolates

\begin{tabular}{lll}
\hline $\begin{array}{l}\text { Sample ESBL } \\
\text { code }\end{array}$ & $\begin{array}{l}\text { Antibiotic resistance by Vitek-2 } \\
\text { genes }\end{array}$ & AM/ AMP/ KZ/ CTX/ CRO/ ATM/ GM/ CIP \\
\hline 137 & CTX & AM/AMP/KZ/CTX/CRO/ATM/ GM/ CIP / SXT \\
138 & CTX & AM/AM/ \\
139 & CTX & AM/AMP/KZ/CTX/CRO/ATM/ GM/ CIP/ SXT \\
140 & TEM & AM/ AMP/ KZ/ CTX/ CRO/ ATM/ GM/ CIP \\
141 & CTX, & AM/AMP/KZ/CTX/CRO/ ATM/ GM/ CIP/ SXT \\
142 & TEM & AM/ AMP/ KZ/ CTX/ CRO/ GM/ CIP \\
143 & CTX & AM/AMP/SAM/KZ/CTX/CAZ/CRO/ATM/SXT \\
144 & CTX & AM/ AMP/ KZ/ CTX/ CRO/ ATM/ GM/ SXT \\
145 & CTX & AM/ AMP/ KZ/ CTX/ CRO/ ATM/ GM/ SXT \\
146 & CTX & AM/ AMP/ KZ/ CTX/ CRO/ GM/ SXT \\
\hline
\end{tabular}

Note: AM: Amoxicillin, AMP: Ampicillin, SAM: Ampicillin/ sulbactam, TZP: Piperacillin/Tazobactam, KZ: Cefazolin, CTX: Cefotaxime, CAZ: Ceftazidime, CRO: Ceftriaxone, FEP: Cefepime, ATM: Aztreonam, ERT: Ertapenem, MEM: meropenem, AK: Amikacin, GM: Gentamicin, CIP: Ciprofloxacin, TC: Tigecycline, NFT: Nitrofurantoin, SXT: Trimethoprim/ sulfamethozale

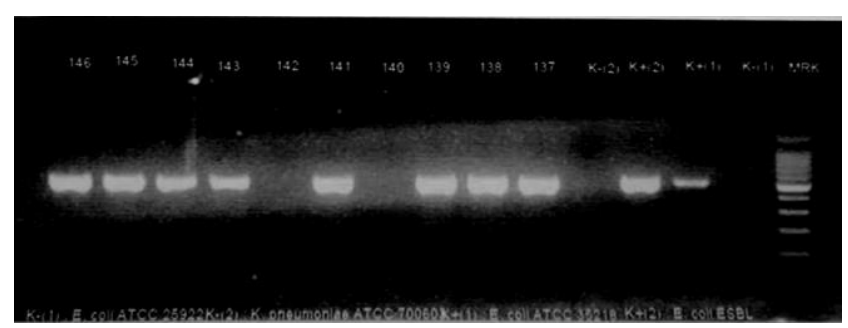

Figure 1. Molecular identification of CTX gene by PCR (PCR product $=550 \mathrm{bp})$. Note: 137-146 samples code; K-: negative control; $\mathrm{K}+$ : positive control for CTX gene; MRK: marker

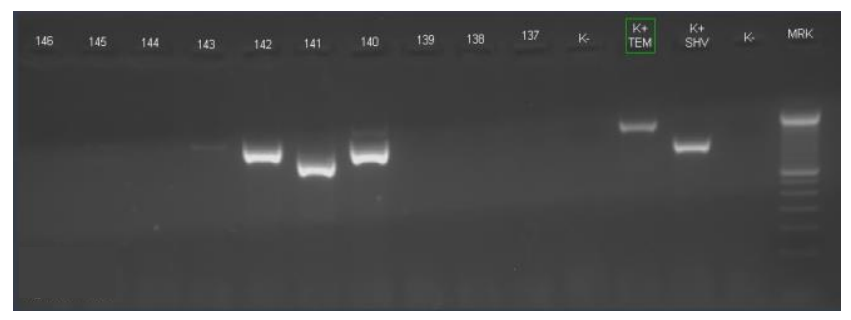

Figure 2. Molecular identification of TEM, and SHV genes by PCR (PCR product for TEM gene $=1080 \mathrm{bp}$ and PCR product for SHV gene = 927 bp). Note: 137-146 samples code; K-: negative control; K+ TEM: positive control for TEM gene; K+ SHV: positive control for SHV gene; MRK: marker 


\section{Discussion}

The prevalence of $E$. coli producing ESBL in cloacal swabs in laying hens is in accordance with the prevalence of $E$. coli in livestock in slaughterhouses in Bogor by $8.6 \%$ (Sudarwanto et al. 2016), but much smaller compared to the incidence of ESBL producing $E$. coli from animal feces of broiler chickens in Bogor by 25\% (Masruroh et al. 2016) and the prevalence of ESBL producing E. coli in India in laying hens by $42 \%$ (Brower et al. 2017).

Extended-spectrum beta-lactamases-producing E. coli in poultry spread through the food chain. In Indonesia, the desire to optimize poultry farming has led to the use of antibiotics without referring to pharmaceutical standards, which was similar to research in Zambia (Chishimba et al. 2016). The use of many antibiotics has been reported to be a risk factor for the acquisition of ESBL-producing organisms resulting in a trend of increasing resistance to commonly used antibiotics, namely, ampicillin, cotrimoxazole, gentamicin, erythromycin, tetracycline, and third-generation cephalosporins (Reich et al. 2013).

In Blitar, the antimicrobial agents are used for poultry without proper guidance on drug dispensation. Inadequate monitoring of drug stores in Blitar has made it easy for people to access livestock antibiotics without following the advice recommended by veterinarians thereby increasing the risk of ESBL in poultry products. This is also similar to the condition reported on dairy farms in East Java (Putra et al. 2019). The high prevalence observed may be due to the frequent use of uncontrolled antibiotics for animal health which in turn increases the risk of $E$. coli, being more resistant to antimicrobial strains in normal intestinal flora as observed in a study conducted by Carattoli (2008) and also by Wibisono et al. (2020). Detection of ESBLproducing $E$. coli isolates in poultry has not been fully carried out in Indonesia. Cross-sectional study revealed that overall of almost $10 \%$ of ESBL-producing $E$. coli isolates was detected on dogs (Kristaningtyas et al. 2020).

To detect the presence of $E$. coli the cloacal swabs method was used in the present study. Furthermore, high colonization can be associated with cross-contamination of poultry farms potentially causing risk factors that can worsen the transmission rate of ESBL-producing E. coliresistant genes (Lavilla et al. 2008).

The dominant ESBL-producing $E$. coli gene identified in this study was the CTX cluster with $80 \%$ which was relatively high in relation to $54.5 \%$ of the CTX E. coli carriers isolated from poultry in the UK (Randall et al. 2011). In Blitar, the economic situation has caused many residents to grow layer chicken as a business that generates more income. This is what brings humans into close contact with poultry which can be a possible route for releasing environmental ESBL producers. However, there are no detailed studies conducted in Indonesia to specifically explain the types of ESBL-producing Enterobacteriaceae associated with chickens and their products. Other studies of poultry products clarify the presence of ESBL gene from Enterobacteriaceae (Effendi et al. 2018; Pehlivanoglu et al. 2017). In addition, other researchers also showed that ESBL produced E. coli isolates carrying several types of beta-lactamase genes and that the combination of CTX-was dominant followed by the TEM cluster (Putra et al. 2019).

This study using an antimicrobial susceptibility test with VITEK ${ }^{\circledR} 2$ compacts in this ESBL isolate revealed an interesting pattern with the level of resistance observed in most of the antimicrobial agents tested. The results on ESBL isolates with $100 \%$ antimicrobial susceptibility to amoxicillin, ampicillin, cefazolin, cefotaxime, and ceftriaxone and more than $70 \%$ resistant to gentamicin, aztreonam, trimethoprim/sulfamethoxazole were similar the findings of Tutun et al. (2019).

In this study, it was found that isolates ESBL producing $E$. coli have resistance to 2 cephalosporin third-generation class antibiotics. One isolate of ESBL contained two ESBL genes. Therefore, this confirms that the ESBL-mediated plasmid is capable of carrying more than one betalactamase gene and thus produces a high level of betalactam resistance phenotype as described by Rottier et al. (2012). These results were in accordance with previous studies on dogs identified that $E$. coli strain consisting of CTX as the main ESBL-producing subtype isolated and also carrying more than one beta-lactamase genes (Kristianingtyas et al. 2020).

In conclusion, molecular identification of CTX, TEM, and SHV genes in ESBL-producing E. coli in laying hens cloacal swabs in Blitar Regency was dominant in CTX encoding genes of $8(8 / 10,80 \%)$, followed by TEM encoding genes of 2 (8) 2/10, 20\%), and while the SHV encoding gene is $1(1 / 10,10 \%)$. One isolate ESBL producing $E$. coli was found containing two genes encoding ESBL. These results also indicate the presence of ESBL isolates that are $100 \%$ resistant to some antibiotics and also the wider distribution on laying hens in Blitar that can threaten animal health and human health.

\section{ACKNOWLEDGEMENTS}

The authors would like to thank the Rector of Airlangga University, Surabaya, Indonesia for providing Hibah Mandat research funds with grant numbers; $371 / \mathrm{UN} 3.14 / \mathrm{LT} / 2019$, and this article is a part of the research.

\section{REFERENCES}

Ali T, Rahman S, Zhang L, Shahid M, Zhang S, Liu G, Gao, J and Han, B. 2016. ESBL Producing Escherichia coli from cows suffering mastitis in China Contain Clinical Class 1 Integrons with CTX-M Linked to ISCR1. Front Cell Infect Microbiol 7: 1931. DOI: 10.3389/fmicb.2016.01931.

Biomerieux. 2017. AST and resistance detection, antibiotic suceptibility testing bioMérieux Industry. bioMérieux SA, France.

Biutifasari V. 2018, Extended spectrum beta-lactamase (ESBL). Ocean Biomed J 1: 1-6.

Bradford P. 2001, Extended spectrum beta-lactamase in the 21 century: characterization, epidemiology, and detection of this important resistant threat. Clin Microbiol Rev14: 933-951.

Brower CH, Mandal S, Hayer S, Sran M, Zehra A, Patel SJ, Kaur R, Chatterjee L, Mishra S, Das BR, Singh P, Singh R, Gill JPS, Laxminarayan R. 2017. The prevalence of Extended-spectrum betalactamases-producing multidrug-resistant Escherichia coli in poultry chickens and variation according to farming practices in Punjab, 
India. Environ Health Perspect 125: 1-10. DOI: $10.1089 / \mathrm{mdr} .2018 .0431$.

Carattoli A. 2008, Animal reservoirs for Extended-spectrum betalactamases producers. Clin Microbiol Infect 14: 1: 117-123.

Chishimba K, Hang'ombe BM, Muzandu K, Mshana SE, Matee MI Nakajima C, Suzuki Y. 2016, Detection of extended-spectrum betalactamases-producing Escherichia coli in market-ready chickens in Zambia. Intl J Microbiol 2016: 5275724. DOI: $10.1155 / 2016 / 5275724$.

CLSI. 2017, M100 Performance Standards for Antimicrobial. 27th ed Clinical and Laboratory Standards Institute, USA.

Effendi MH, Bintari IG, Aksoro EB, Hermawan IP. 2018, Detection of blaTEM gene of Klebsiella pneumoniae isolated from swab of foodproducing animals in East Java. Trop Anim Sci J 41: 174-178.

Effendi MH, Harijani N, Budiarto, Triningtya NP, Tyasningsih W, Plumeriastuti H. 2019, Prevalence of pathogenic Escherichia coli isolated from subclinical mastitis in East Java Province, Indonesia. Indian Vet J 96 (3): 22-25.

Hammerum AM, Larsen J, Andersen VD, Lesterm CH, Timmy S, Skytte TSS, Hansen F, Olsen SS, Mordhorst H, Skov RL, Aarestrup FM, Agerso Y. 2014, Characterization of Extended-spectrum betalactamases (ESBL)-producing Escherichia coli obtained from Danish pigs, pig farmers and their families from farms with high or no consumption of third- or fourth-generation cephalosporins. J Antimicrob Chemother 69: 2650-2657.

Kang D, Sinuraya RK, Rostinawati T, Abdulah R. 2017, Gene blaCTX-M mutation as risk factor of antibiotic resistance. J Farmasi Klinik Indonesia 6: 135-152.

Kristianingtyas L, Effendi MH, Tyasningsih W, Kurniawan F. 2020 Genetic identification of blactx-M gene and blatem gene on extendedspectrum beta-lactamases (ESBL) producing Escherichia coli from Dogs. Indian Vet J 97 (1): 17-21.

Kürekci C, Aydin M, Yipel M, Katouli M, Gündogdu A 2017, Characterization of extended-spectrum $\beta$-lactamase (ESBL)producing Escherichia coli in Asi (Orontes) River in Turkey. J Water Health 15: 788-798.

Kurniawati AF, Satyabakti P, Arbianti N. 2015, Differences in risk of multidrug resistance organisms (MDROS) according to risk, compliance and hygiene factors. J Berk Epidemiol 3: 277-289.

Lavilla S, Gonzalez-Lopez JJ, Miro E, Domınguez A, Llagostera M, Bartolome R M, Mirelis B, Navarro F, Prats G. 2008, Dissemination of extended-spectrum beta-lactamases-producing bacteria: the foodborne outbreak lesson. J Antimicrob Chemother 61: 6: 12441251.

Lim CLL, Lee W, Lee ALC, Liew LTT, Nah SC, Wan CN, Chlebick MJP, Kwa ALH. 2013, Evaluation of ertapenem use with impact assessment on Extended-spectrum beta-lactamasess (ESBL) production and gram-negative resistance in Singapore general hospital (SGH). BMC Infect Dis 13: 1523. DOI: 10.1186/1471-233413-523.

Masruroh CA, Sudarwanto MB, Latif H. 2016, Incidence rate of Escherichia coli producing extended-spectrum beta-lactamases isolated from broiler faeces in Bogor City. J Sains Vet 34: 42-49.

Paterson DL, Bonomo RA. 2005, Extended-spectrum beta-lactamasess: a Clinical Update. Clin Microbiol Rev 18: 657-686.
Pehlivanoğlu F, Turutoğlu H, Ozturk D, Yardimci, H. 2017, Characterization of extended-spectrum beta-lactamases-producing fecal Escherichia coli isolates in laying hens. Ankara Univ Vet Fak Derg 64: 301-306.

Putra ARS, Effendi MH, Koesdarto S, Tyasningsih W. 2019, Molecular identification of extended-spectrum beta-lactamases (ESBL) producing Escherichia coli isolated from dairy cows in East Java Province, Indonesia. Indian Vet J 96: 10: 26-30.

Putra AR, Effendi MH, Koesdarto S, Suwarno S, Tyasningsih W, Estoepangestie AT. 2020, Detection of the extended-spectrum $\beta$ lactamase produced by Escherichia coli from dairy cows by using the Vitek-2 method in Tulungagung regency, Indonesia. Iraqi J Vet Sci 34 (1): 203-207.

Randall LP, Clouting C, Horton RA, Coldham NG, Wu G, Clifton-Hadley FA, Davies RH, Teale CJ. 2011, Prevalence of Escherichia coli carrying extended-spectrum beta-lactamasess (CTX-M and TEM-52) from broiler chickens and turkeys in Great Britain between 2006 and 2009. J Antimicrob Chemother 66 (1): 86-95.

Reich F, Atanassova V, Klein G, (2013, Extended-spectrum betalactamases- and ampc-producing Enterobacteria in healthy broiler chickens, Germany. Emerg Infect Dis 19: 1253-1259.

Rottier WC, Ammerlaan HSM, Bonten MJM. 2012, Effects of confounders and intermediates on the association of bacteremia caused by extended-spectrum $\beta$-lactamase-producing Enterobacteriaceae and patient outcome: a meta-analysis. J Antimicrob Chemother 67 (6): 1311-1320.

Saliu EM, Vahjen W, Zentek J. 2017, Types and prevalence of extendedspectrum beta-lactamases-producing Enterobacteriaceae in poultry. Anim Heal Res Rev 18: 46-57.

Seni J, Falgenhauer L, Simeo N, Mirambo MM, Imirzalioglu C, Matee M, Rweyemamu M, Trinad Chakraborty T, Mshana SE. 2016, Multiple ESBL-producing Escherichia coli sequence types carrying quinolone and aminoglycoside resistance genes circulating in companion and domestic farm animals in Mwanza, Tanzania, harbor commonly occurring plasmids. Front Microbiol 7: 142. DOI: 10.3389/fmicb.2016.00142.

Suardana IW, Utama IH, Putriningsih PAS, Rudyanto MD. 2014, Antibiotic sensitivity test of Escherichia coli O157: H7 isolates from chicken feces. Bul Vet Udayana 6: 19-27.

Sudarwanto MB, Lukman DW, Latif H, Pisestyani H, Sukmawinata E, Akineden Ö, Usleber E. 2016, CTX-M producing Escherichia coli isolated from cattle feces in Bogor slaughterhouse, Indonesia. Asian Pac J Trop Biomed 6: 605-608.

Sudarwanto MB, Lukman DW, Purnawarman T, Latif H, Pisestyani H, Sukmawinata E. 2017, Multidrug resistance extended-spectrum betalactamases and $\mathrm{AmpC}$ producing Escherichia coli isolated from the environment of Bogor Slaughterhouse, Indonesia. Asian Pac J Trop Biomed 7: 708-711.

Tutun H, Karagoz A, Altintas L, Kocak N. 2019, Determination of antibiotic susceptibility, ESBL genes, and pulsed-field gel electrophoresis profiles of extended-spectrum $\beta$-lactamase-containing Escherichia coli isolates. Ankara Univ Vet Fak Derg 66: 407-416.

Wibisono, F.J. Sumiarto, B, Untari, T, Effendi, M.H, Permatasari, D.A, Witaningrum. A.M. 2020. The presence of extended-spectrum betalactamases (ESBL) producing Escherichia coli on layer chicken farms in Blitar Area, Indonesia. Biodiversitas 21 (6): 2667-2671. 